\title{
Eteksylan dabigatranu a idarucizumab - przełomowe rozwiązanie problemów klinicznych związanych z przeciwkrzepliwym działaniem leku
}

\section{Dabigatran etexilate and idarucizumab - a breakthrough in clinical problems associated with its anticoagulative action}

\author{
Agnieszka Styczeń, Maria Falkiewicz, Marta Karaś-Głodek, \\ Andrzej Wysokiński, Tomasz Zapolski
}

Katedra i Klinika Kardiologii Uniwersytetu Medycznego w Lublinie

\section{Streszczenie}

Przewlekłe leczenie przeciwkrzepliwe znajduje zastosowanie w leczeniu i zapobieganiu powikłaniom zakrzepowo-zatorowym. Przez wiele lat standardem w doustnej antykoagulacji były leki z grupy antagonistów witaminy K (VKA). Ich stosowanie wiąże się ze zwiększonym ryzykiem powikłań krwotocznych i interakcji z wieloma lekami oraz koniecznością stałego monitorowania parametrów układu krzepnięcia.

W związku z ograniczeniami w terapii VKA, w ciągu ostatnich lat zsyntetyzowano leki przeciwkrzepliwe niebędące antagonistami witaminy (NOAC) - dabigatran, riwaroksaban i apiksaban. Pierwszym lekiem z tej grupy, który został włączony w zakres zalecanych leków przeciwzakrzepowych jest bezpośredni inhibitor trombiny - eteksylan dabigatranu.

Pozytywnym aspektem wprowadzenia leku okazał się brak konieczności monitorowania efektu antykoagulacyjnego dabigatranu w codziennej praktyce lekarskiej z uwagi na krótki okres półtrwania substancji, szerokie okno terapeutyczne oraz stosowanie stałych dawek leku w badaniach klinicznych.

Jednym z działań niepożądanych dabigatranu są poważne, zagrażające życiu krwawienia. Niemniej istotna jest także spotykana często w praktyce klinicznej konieczność szybkiego odwrócenia przeciwkrzepliwego działania dabigatranu u chorych wymagających pilnej interwencji chirurgicznej lub zahamowania krwawienia po ciężkich urazach. Konieczne jest zatem opracowanie skutecznego antidotum, które mogłoby specyficznie i szybko odwracać efekt antykoagulacyjny leku.

Niniejsza praca przedstawia trudności w monitorowaniu działania eteksylanu dabigatranu, problemy kliniczne spotykane u pacjentów leczonych tym lekiem. Przedstawiono także wyniki prospektywnego badania kohortowego RE-VERSE AD (Reversal Effects of Idarucizumab on Active Dabigatran), w którym badano skuteczność i bezpieczeństwo idarucizumabu - swoistego antidotum dla leku - w odwracaniu przeciwkrzepliwego działania dabigatranu u pacjentów z poważnym krwawieniem lub u chorych wymagających pilnej interwencji chirurgicznej.

Słowa kluczowe: dabigatran, idarucizumab, leczenie przeciwzakrzepowe, powikłania krwotoczne

Folia Cardiologica 2016; 11, 4: 284-292

Address for correspondence: dr hab. n. med. Tomasz Zapolski, Katedra i Klinka Kardiologii, Uniwersytet Medyczny w Lublinie, ul. Jaczewskiego 8, 20-950 Lublin, tel. 8172442 55, faks 8172441 51, e-mail: zapolia@wp.pl 


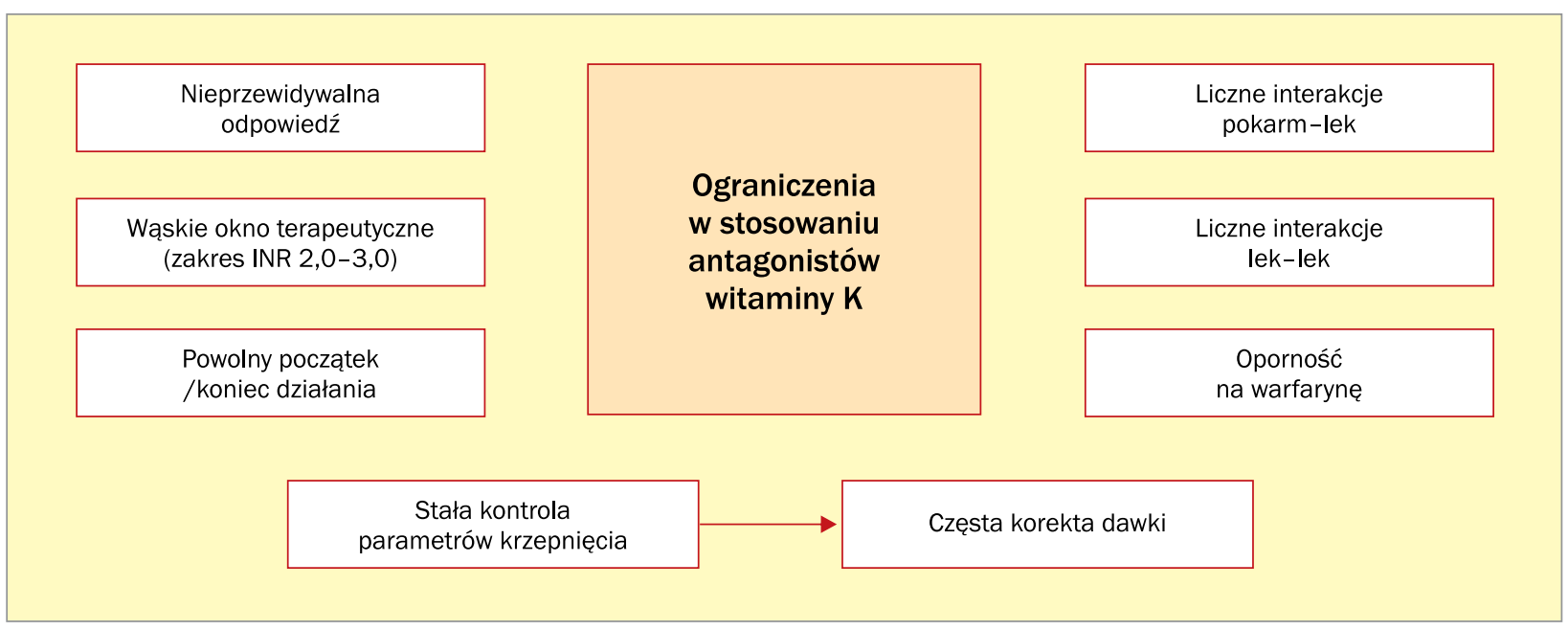

Rycina 1. Ograniczenia antagonistów witaminy K (opracowano na podstawie [10, 11]); INR (international normalized ratio) - międzynarodowy współczynnik znormalizowany

\section{Wstęp}

Doustne antykoagulanty (OAC, oral anticoagulants) są wskazane w leczeniu zakrzepicy i zapobieganiu powikłaniom zakrzepowo-zatorowym [1]. Odnosi się to do leczenia zakrzepicy żył głębokich (DVT, deep vein thrombosis) i zatorowości płucnej (PE, pulmonary embolism), zapobiegania zakrzepicy u pacjentów hospitalizowanych i będących po zabiegach operacyjnych oraz do prewencji udaru niedokrwiennego mózgu u chorych z migotaniem przedsionków (AF, atrial fibrillation) [2]. Do niedawna jedyną dostępną dla lekarzy grupą OAC byli antagoniści witaminy K (VKA, vitamin $\mathrm{K}$ antagonists). Preparaty te są ekonomiczne i bardzo dobrze poznane, maja jednak istotne ograniczenia w swoim stosowaniu, takie jak powolny początek działania, wąski zakres wartości terapeutycznych oraz nieprzewidywalny efekt przeciwkrzepliwy [3] (ryc. 1). Może to prowadzić do zwiększonego ryzyka krwawień lub ograniczonej antykoagulacji i zwiększonego ryzyka incydentów zakrzepowych [4]. Działania uboczne tradycyjnych leków przeciwkrzepliwych skłoniły firmy farmaceutyczne do badań klinicznych pod kątem nowych leków. Dotychczas w praktyce klinicznej zarejestrowano klika OAC niebędących antagonistami witaminy $\mathrm{K}$ (NOAC, non-vitamin $\mathrm{K}$ antagonist oral anticoagulants) o bardziej stabilnych profilach farmakokinetycznych i farmakodynamicznych [4-7]. Aktualnie najszerzej zbadanymi nowymi lekami przeciwkrzepliwymi są dabigatran (bezpośredni inhibitor trombiny), riwaroksaban oraz apiksaban (bezpośrednie inhibitory czynnika Xa) [4-7] (ryc. 2). Pierwszym wprowadzonym na rynek przedstawicielem NOAC był eteksylan dabigatranu [8]. Mimo że stosowanie dabigatranu wiąże się z mniejszym ryzykiem krwawienia niż w przypadku warfaryny, chorzy przyjmujący ten lek mogą wymagać pilnej interwencji chirurgicznej, co często skutkuje zwiększeniem

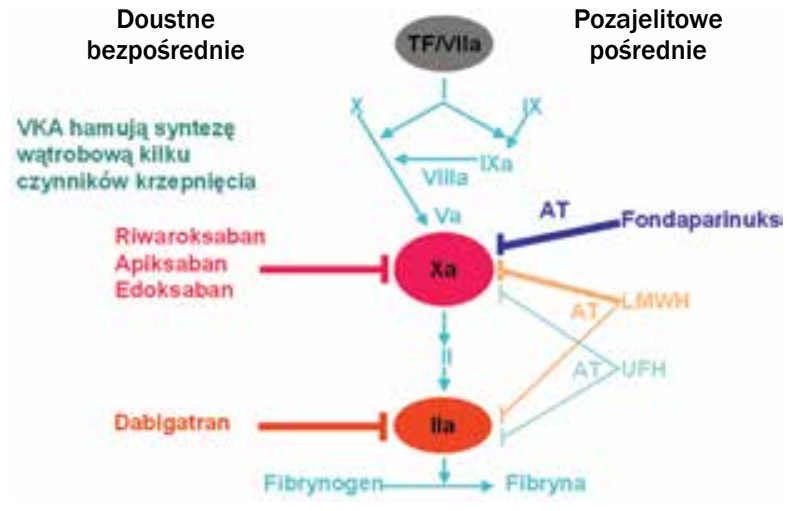

Rycina 2. Cele leczenia przeciwzakrzepowego (opracowano na podstawie [10-12]); VKA (vitamin K antagonists) - antagoniści witaminy K; LMWH (low-molecular-weight heparin) - heparyna drobnocząsteczkowa; UFH (unfractionated heparin) - heparyna niefrakcjonowana

prawdopodobieństwa wystąpienia krwawienia okołooperacyjnego. Aby ułatwić postępowanie lecznicze w takich przypadkach klinicznych, korzystne byłoby zastosowanie swoistego antidotum dla dabigatranu [9].

\section{Trudności w monitorowaniu parametrów układu krzepnięcia w trakcie terapii dabigatranem}

Monitorowanie działania przeciwkrzepliwego dabigatranu jest znacznie trudniejsze niż VKA. Badanie międzynarodowego współczynnika znormalizowanego (INR, international normalized ratio) nie znajduje zastosowania w tej grupie pacjentów [13]. Wartość INR jest względnie niewrażliwa na indukowaną dabigatranem antykoagulacje, pozostając 
niezmienioną lub prawie niezmienioną w przypadku terapeutycznych stężeń osoczowych leku i wzrastając tylko nieznacznie w przypadku jego wyższych stężeń [14-16].

Dabigatran wpływa na kilka parametrów układu krzepnięcia, takich jak czas częściowej tromboplastyny po aktywacji (APTT, activated partial thromboplastin time), czas protrombinowy (PT, prothrombin time), czas trombinowy (TT, thrombin time) i ekarynowy czas krzepnięcia (ECT, ecarin clotting time) $[14,17]$.

Test TT jest przydatny do oceny stężenia dabigatranu w osoczu, gdyż wykazuje liniową zależność. Jednakże TT może być zbyt czuły w zakresie stężeń spotykanych klinicznie; już przy małych stężeniach dabigatranu TT jest nieoznaczalny i dlatego nie nadaje się do precyzyjnego monitorowania. Problem można przezwyciężyć przy użyciu zmodyfikowanego testu TT (rozcieńczony TT [dTT]). Ponadto do standaryzacji istniejących lub zmodyfikowanych testów TT konieczne są zwalidowane kalibratory i odczynniki kontrolne [18].

W celu dokonania jakościowej oceny działania eteksylanu dabigatranu można oznaczyć APTT, który zależy od czułości użytego aktywatora i typu koagulometru [18]. Relacja między osoczowym stężeniem związku a wydłużeniem APTT ma charakter krzywoliniowy, w zależności od rodzaju zastosowanego testu mogą pojawiać się istotne różnice [13]. Czas ten ulega 1,5-3-krotnemu wydłużeniu, ale nie odzwierciedla w sposób całkowicie wiarygodny efektu przeciwkrzepliwego. Wydłużenie APTT powyżej 65-80 s bezpośrednio przed kolejną dawką leku może wskazywać na nadmierną antykoagulację [18].

Czas protrombinowy jest mniej czuły niż APTT; jego wydłużenie jest zmienne, dlatego nie jest zalecany do monitorowania dabigatranu [18].

Przedłużony aktywowany czas krzepnięcia (ACT, activated clotting time) oznaczany metodą szybkiej tromboelastografii może wskazywać na zwiększone ryzyko krwawień u pacjentów przyjmujących dabigatran i hospitalizowanych z powodu poważnych urazów [18]. Potencjalnie zalecanym badaniem do monitorowania działania przeciwkrzepliwego dabigatranu jest oznaczenie czasu trombinowego w rozcieńczonym osoczu (dTT, diluted thrombin time), które pozwala na ilościowy pomiar dabigatranu w osoczu, wyrażony w sekundach lub ng/ml [18].

Specjalnie przeznaczonym dla oceny aktywności dabigatranu jest ECT, jednak badanie to nie jest jeszcze powszechnie dostępne [15]. Podczas stosowania dabigatranu w dawce 150 mg dwa razy na dobę występuje 2-4-krotne wydłużenie ECT, korelując z większym ryzykiem wystąpienia powikłań krwotocznych $[18,19]$.

\section{Problemy kliniczne u chorych przyjmujących dabigatran}

Przedawkowanie dabigatranu wiąże się ze wzrostem ryzyka krwawienia, które może wystąpić także przy stoso- waniu leku w prawidłowych dawkach. W retrospektywnym badaniu kohortowym obejmującym 21033 pacjentów z niezastawkowym AF przyjmujących dabigatran ryzyko krwawienia u chorych z AF było istotnie związane z wiekiem - w porównaniu z chorymi w wieku poniżej 55. roku życia, chorzy w wieku 64, 65-74 i 75 lub więcej lat prezentowali uśrednione współczynniki ryzyka (aHR, average hazard ratio) odpowiednio 1,54 (95-proc. przedział ufności [Cl, confidence interval] 0,89-2,68), 2,72 (95\% Cl 1,59-4,65) oraz 4,52 (95\% Cl 2,68-7,64). Upośledzenie funkcji nerek (aHR 1,67; 95\% Cl 1,24-2,25), niewydolność serca (aHR 1,25; 95\% Cl 1,01-1,56), nadużywanie alkoholu (aHR 2,57; $95 \% \mathrm{Cl} 1,52-4,35)$, przebyta infekcja Helicobacter pylori (aHR 4,75; 95\% Cl 1,93-11,68), terapia przeciwpłytkowa (aHR 1,49; 95\% Cl 1,19-1,88) oraz stosowanie digoksyny (aHR 1,49, 95\% Cl 1,19-1,88) również korelowały ze zwiększoną możliwością powikłań krwotocznych w obrębie przewodu pokarmowego. Do terapii przeciwkrzepliwej dabigatranem po przebytym epizodzie krwawienia do przewodu pokarmowego powróciło mniej niż 50\% pacjentów [20].

\section{Niecelowane postępowanie terapeutyczne w krwawieniach spowodowanych dabigatranem}

Postępowanie terapeutyczne w krwawieniach związanych ze stosowaniem dabigatranu zależy od stopnia utraty krwi, nasilenia objawów klinicznych związanych z krwawieniem, czasu przyjęcia oraz wielkości dawki i możliwości eliminacji leku zależnej głównie od wydolności nerek (ryc. 3).

W przypadku niedawnego przyjęcia zbyt dużej dawki eteksylanu dabigatranu można rozważyć węgiel aktywowany w celu redukcji absorpcji leku [21, 22]. Właściwym postępowaniem jest podanie węgla w typowych dawkach dla ludzi dorosłych 30-50 g w przeciągu 1-2 godzin od przyjęcia leku. Po czasie powyżej 2 godzin weggiel aktywowany jest nieskuteczny [15, 21, 22]. Dalsze postępowanie terapeutyczne zależy od intensywności krwawienia. W przypadku krwawienia o niewielkim nasileniu, w związku ze względnie krótkim czasem półtrwania eliminacji dabigatranu, może wystarczyć odstawienie leku [23]. Po przerwaniu leczenia przywrócenie prawidłowej hemostazy następuje w przeciągu 12-24 godzin od ostatniej przyjętej dawki dabigatranu. Kiedy krwawienie ma duże nasilenie, wymagane mogą być ogólne środki, takie jak kompresja mechaniczna, hemostaza chirurgiczna, płynoterapia wymienna czy inne zabiegi wspierające hemodynamikę ustroju. Czasowy przedział eliminacji dabigatranu w znacznym stopniu zależy od funkcji nerek; w celu przyspieszenia tego procesu zaleca się utrzymanie właściwego nawodnienia i diurezy u pacjenta $[4,23]$. Nerkowy szlak eliminacji jest główną drogą wydalania leku u chorych otrzymujących dabigatran. Do 80\% niezmienionego krążącego dabigatranu i niewielkie ilości glukuronidów dabigatranu są wydalane przez nerki [4]. U pacjentów z upośledzoną funkcją nerek można rozważyć 


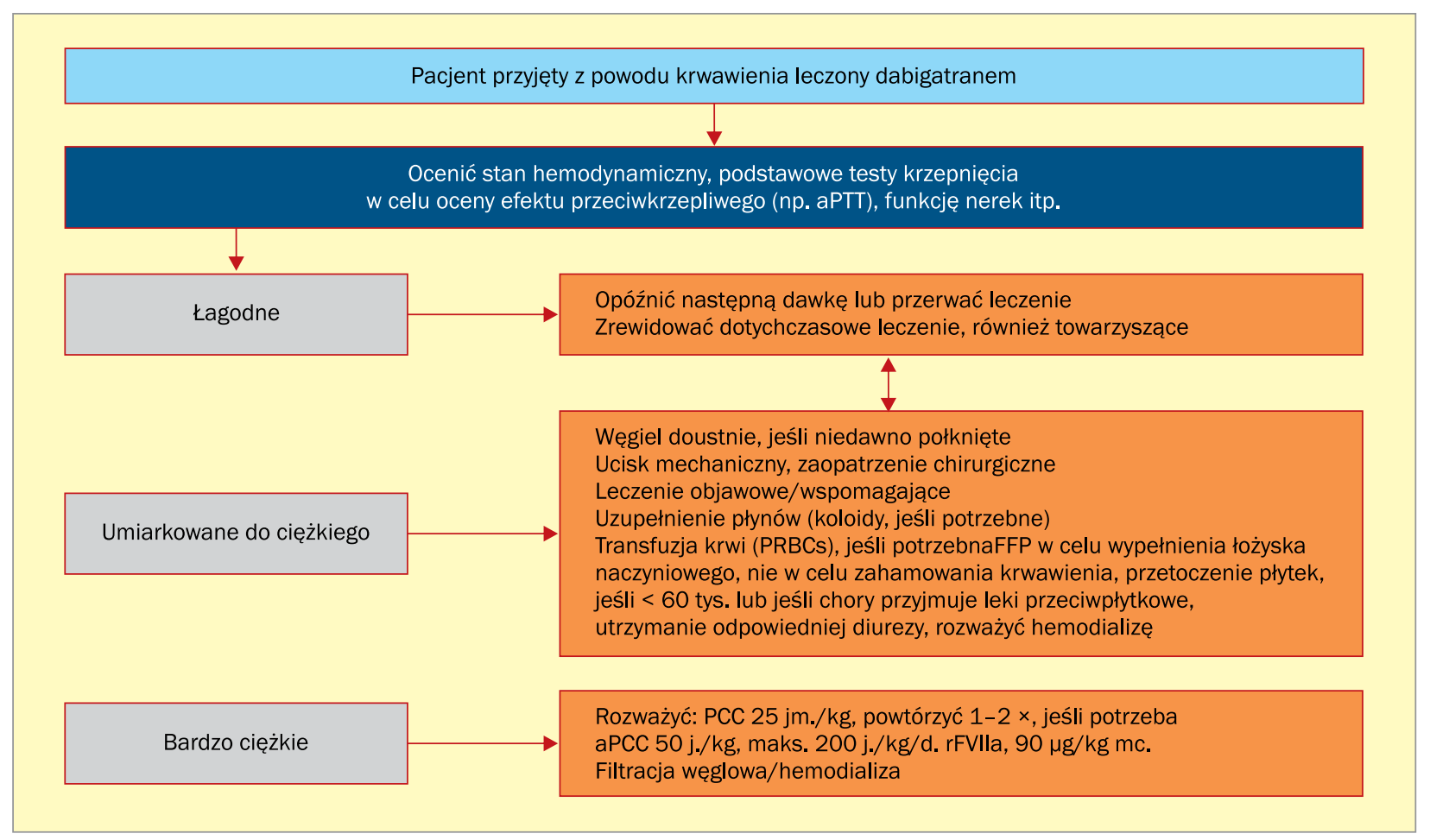

Rycina 3. Postępowanie terapeutyczne w krwawieniach związanych ze stosowaniem dabigatranu (opracowano na podstawie [20]); aPTT (activated partial thromboplastin time) - czas częściowej tromboplastyny po aktywacji; PCC (prothrombin complex concentrate) - koncentrat czynników zespołu protrombiny; PT (prothrombin time) - czas protrombinowy; rFVIla (recombinant activated factor VII) - rekombinowany aktywny czynnik VII; PRBCs (packed red blood cells) - koncentrat krwinek czerwonych; FFP (fresh frozen plasma) - świeżo mrożone osocze

wykonanie hemodializy, jednak doświadczenia z tą metodą postępowania są ograniczone [4].

W krwawieniach zagrażających życiu wymagane jest zintensyfikowane postępowanie lecznicze. Celowe powinno być użycie procedur ratujących życie, takich jak wentylacja mechaniczna i infuzja leków wazopresyjnych [23]. Zwykle ryzyko związane ze stosowaniem tych procedur jest mniejsze od ryzyka związanego z nieleczonym krwotokiem. Istnieją pewne dowody eksperymentalne potwierdzające rolę czynników hemostazy, takich jak koncentrat czynników zespołu protrombiny (PCC, prothrombin complex concentrate; koncentrat II, VII, IX i X czynnika krzepnięcia) czy rekombinowany czynnik VIla, w odwracaniu aktywności przeciwkrzepliwej leku w sytuacji dużych krwotoków [24, 25]. Wyniki badań dla eteksylanu dabigatranu nie są jeszcze jednak do końca jasne [26]. Podawanie PCC można rozpocząć od dawki 25 j./kg i powtarzać w zależności od sytuacji klinicznej. Badania u zdrowych ochotników wykazały, że aktywowany koncentrat zespołu czynników protrombiny (aPCC, np. podobny do PCC, ale z aktywowanym czynnikiem VII) normalizował parametry układu krzepnięcia w większym stopniu niż sam PCC [23, 27]. Rekombinowany aktywowany czynnik VII jest zatwierdzonym silnym prokoagulantem i ogólnym związkiem hemostatycznym w miejscach krwa- wienia, wywierając działanie poprzez bezpośrednią aktywację trombiny na powierzchni płytek krwi w nieobecności czynnika tkankowego (TF, tissue factor) [28]. W związku z tym rekombinowany czynnik VIla został zaproponowany jako substancja mająca potencjał w odwracania skutków działania dabigatranu $[28,29]$.

\section{Postępowanie okołooperacyjne u pacjentów leczonych dabigatranem}

Czasowe zaprzestanie przyjmowania eteksylanu dabigatranu może być wskazane u pacjentów chirurgicznych, w zależności od pilności zabiegu, ryzyka krwawienia z nim zawiązanego oraz wydolności nerek [23]. Decyzja o przerwaniu leczenia dabigatranem w operacjach elektywnych i w trybie nienagłym opiera się na stosunku ryzyka krwawienia do ryzyka zakrzepicy [23] (tab. 1). Podczas zabiegów operacyjnych z małym ryzykiem krwotoku Europejskie Stowarzyszenie Zaburzeń Rytmu Serca (EHRA, European Heart Rhythm Association) zaleca zaprzestanie podawania leku na 18-24 godzin przed operacją i jego ponowne włączenie do leczenia 6 godzin po zabiegu. Dłuższe przerwy w leczeniu mogą być potrzebne u pacjentów, którzy są poddawani zabiegom o wysokim ryzyku krwawienia, 
Tabela 1. Postępowanie u chorych przyjmujących dabigatran przed planowanym zabiegiem operacyjnym w zależności od ryzyka krwawienia i klirensu kreatyniny (źródło [23])

\begin{tabular}{lcc}
$\begin{array}{l}\text { Klirens kreatyniny } \\
{[\mathrm{ml} / \mathrm{min}]}\end{array}$ & Niskie ryzyko & Wysokie ryzyko \\
$>80$ & $\geq 24$ & $\geq 48$ \\
$50-80$ & $\geq 36$ & $\geq 72$ \\
$30-50$ & $\geq 48$ & $\geq 96$ \\
$15-30$ & \multicolumn{2}{c}{ Niewskazane } \\
$<15$ & Bez oficjalnych wskazań do zastosowania
\end{tabular}

zaliczając do tej grupy duże operacje brzuszne, zabiegi na układzie sercowo-naczyniowym, ortopedyczne czy operacje wenątrzczaszkowe [23].

Pilna interwencja chirurgiczna powinna być odłożona, jeżeli to możliwe, na 12 godzin lub najlepiej na 24 godziny po ostatniej dawce dabigatranu [23]. Należy rozważyć ocenę powszechnych badań układu krzepnięcia (PTT, PT) albo specyficznego parametru (ECT), jeżeli istnieje wątpliwość co do farmakokinetycznego osłabienia działania przeciwkrzepliwego związku. Strategia ta nie została jednak nigdy oceniona i nie powinna być zalecana oraz stosowana rutynowo [30]. W niektórych przypadkach pilnych dużych zabiegów operacyjnych chorzy mogą wymagać wymiany osocza lub płytek krwi dodatkowo oprócz krwinek czerwonych. Należy używać PCC, aPCC lub czynnika VIla jako postępowanie ostateczne, gdy w sytuacjach krwotoków zagrażających życiu inne sposoby leczenia zawiodły [23, 31, 32] (ryc. 4).

\section{Idarucizumab - swoiste antidotum dla dabigatranu}

Idarucizumab, fragment przeciwciała monoklonalnego, wiąże dabigatran z 350-krotnie większym powinowactwem niż trombina [15, 33]. Co za tym idzie, idarucizumab wiąże wolny i związany z trombiną dabigatran oraz neutralizuje jego aktywność [15, 33]. U młodych, zdrowych ochotników z prawidłową funkcją nerek, u osób w wieku 65-80 lat oraz w wieku 45-80 lat z upośledzeniem funkcji nerek łagodnego lub umiarkowanego stopnia, zastosowanie idarucizumabu skutkowało natychmiastowym i całkowitym odwróceniem przeciwkrzepliwego działania eteksylanu dabigatranu [34-36]. Uwzględniając te wyniki badań, przeprowadzono prospektywne badanie kohortowe w celu zbadania skuteczności i bezpieczeństwa idarucizumabu w odwracaniu przeciwkrzepliwego działania dabigatranu u pacjentów z poważnym krwawieniem lub u chorych wymagających pilnej interwencji chirurgicznej. W dotychczasowej literaturze przedstawiono wyniki badań u pierwszych 90 pacjentów objętych badaniem Reversal Effects of Idarucizumab on Active Dabigatran (RE-VERSE AD).

\section{Grupa pacjentów}

Badaniem objęto 2 grupy dorosłych ( $\geq 18$ lat) przyjmujących dabigatran. Do grupy A zakwalifikowano chorych z jawnym, niekontrolowanym lub zagrażającym życiu krwotokiem, który decyzją lekarza prowadzącego wymagał podania antidotum. Pacjenci z grupy B musieli być poddani zabiegowi chirurgicznemu lub innym procedurom inwazyjnym, które nie mogły odbyć się później niż po 8 godzinach i wymagały

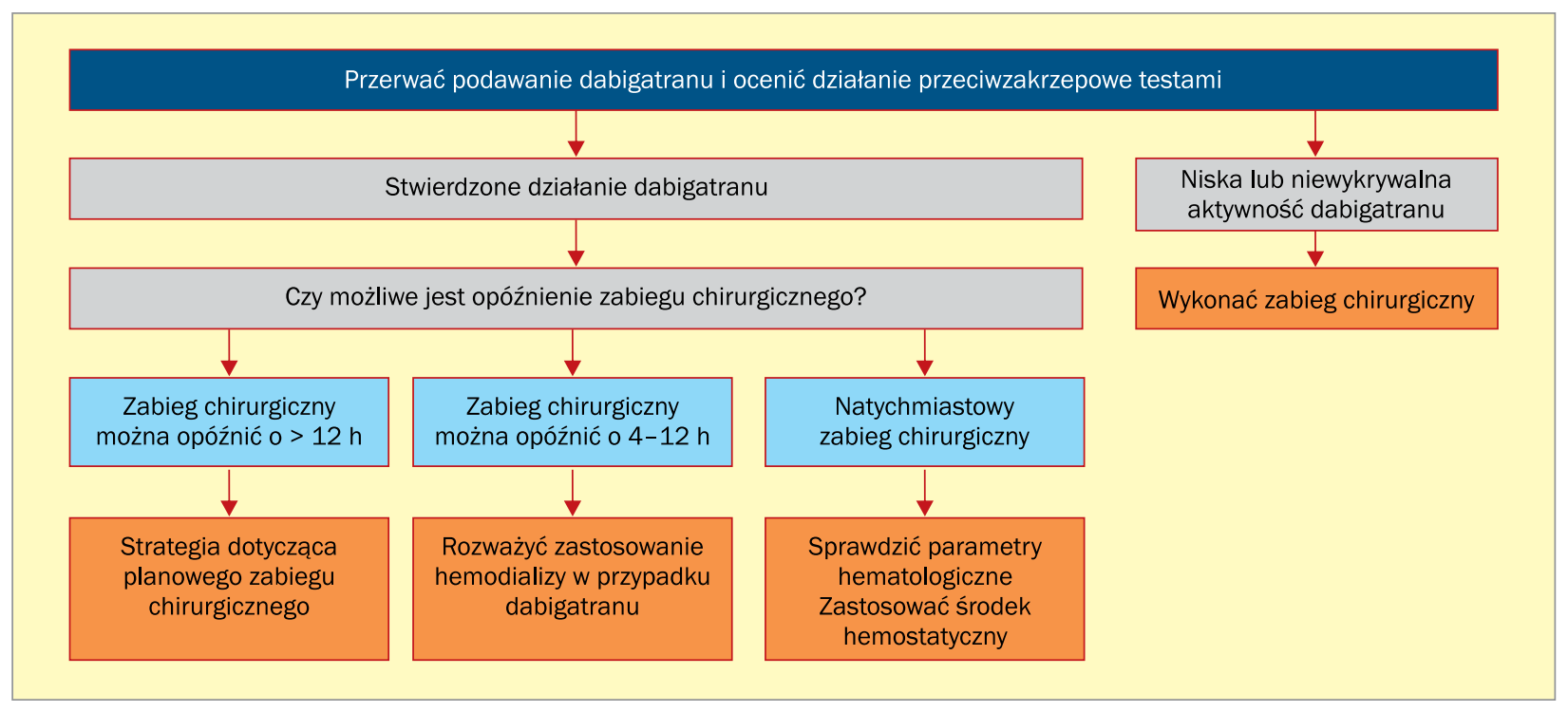

Rycina 4. Algorytm postępowania w przypadku pilnego zabiegu chirurgicznego u pacjentów leczonych dabigatranem (zmodyfikowano wg [32]) 
prawidłowej hemostazy ustroju. W badaniu nie było grupy kontrolnej.

\section{Zastosowane leczenie}

Pacjenci otrzymali 5 g idarucizumabu dożylnie, podanego jako dwa bolusy o objętości $50 \mathrm{ml}$ w odstępie maksymalnie 15-minutowym; każdy bolus zawierał 2,5 g idarucizumabu [9].

\section{Definicje punktów końcowych badania}

Pierwszorzędowym punktem końcowym był maksymalny odsetek odwróceń działania przeciwkrzepliwego dabigatranu, ocenianego w jakimkolwiek momencie od zakończenia pierwszej infuzji idarucizumabu do 4 godzin po drugiej infuzji. Odsetek ewaluowano na podstawie pomiaru dTT lub ECT. Drugorzędowymi punktami końcowymi były odsetek pacjentów, u których dTT lub ECT uległy całkowitej normalizacji w ciągu pierwszych 4 godzin oraz odsetek pacjentów, u których uzyskano zmniejszenie stężenia niezwiązanego dabigatranu [9].

\section{Wyniki badania}

U trzech spośród 51 pacjentów z grupy A nie oceniono wyjściowej intensywności krwawienia. U 13 pacjentów nie ustalono czasu ustania krwawienia; spośród nich 3 miało krwotok wewnątrzczaszkowy, 4 krwawienie z przewodu pokarmowego, 2 krwawienie domięśniowe, 1 krwawienie do worka osierdziowego oraz 1 krwawienie zaotrzewnowe. $\mathrm{U}$ pozostałych chorych średni raportowany czas ustania krwawienia wyniósł 11,4 godziny [9].

Idarucizumab zniwelował potrzebę wykonania hemodializy u jednego pacjenta z grupy $B$, który ciężko przedawkował dabigatran; pomimo odwrócenia działania przeciwkrzepliwego dabigatranu stan ogólny 2 pacjentów z grupy B był zbyt niestabilny do przeprowadzenia zabiegu operacyjnego. Pozostali pacjenci (36 osób) z grupy B zostali poddani pilnym interwencjom chirurgicznym, dzięki którym uzyskano prawidłową hemostazę u 33 pacjentów (92\%). Łagodne i umiarkowane zaburzenia hemostazy podczas leczenia interwencyjnego odnotowano odpowiednio u 2 i 1 pacjenta [9].

Całkowita liczba zgonów wyniosła 18, po 9 w każdej grupie badawczej; 10 zgonów z przyczyn naczyniowych, wliczając w to 5 krwotoków śmiertelnych. Zgon w przeciągu 96 godzin po leczeniu wydawał się wiązać z wskaźnikiem zdarzeń (u 2 pacjentów rozpoznano wstrząs septyczny, u 3 krwotok wewnątrzczaszkowy oraz po jednej niewydolności wielonarządowej, zapaści krążeniowej, niewydolności oddechowej i zatrzymaniu krążenia), podczas gdy wszystkie późne zgony najprawdopodobniej łączyły się z współistniejącymi jednostkami chorobowymi [9].

\section{Epizody zakrzepowe i poważne działania niepożądane}

Zdarzenia zakrzepowe, klasyfikowane jako wczesne (do $72 \mathrm{~h}$ po podaniu idarucizumabu) lub późne ( $>72 \mathrm{~h}$ od podania leku), wystąpiły u 5 pacjentów: zakrzepica żył głębokich i zatorowość płucna pojawiły się u 1 pacjenta 2 dni po leczeniu, zakrzepica żył głębokich, zatorowość płucna oraz skrzeplina w lewym przedsionku rozwinęły się u 1 pacjenta 9 dni po leczeniu, izolowana zakrzepica żył głębokich u 1 pacjenta 7 dni po leczeniu, zawał serca bez uniesienia odcinka ST (NSTEMI, non ST-segment elevation myocardial infarction) wystąpił u 1 pacjenta 13 dni po leczeniu oraz niedokrwienny udar mózgu rozwinął się 26 dni po terapii. Żaden z wcześniej wymienionych pacjentów nie otrzymywał leczenia przeciwkrzepliwego w czasie wystąpienia incydentów [9].

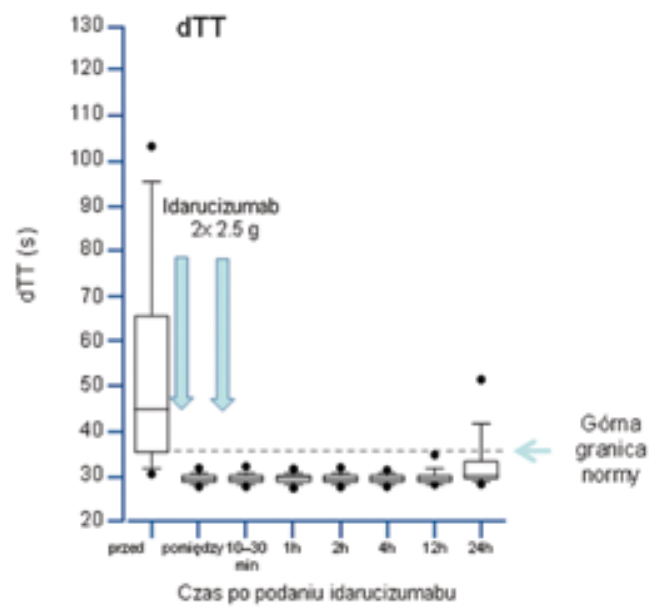

Normalizacja u 98\%, 39/40/51

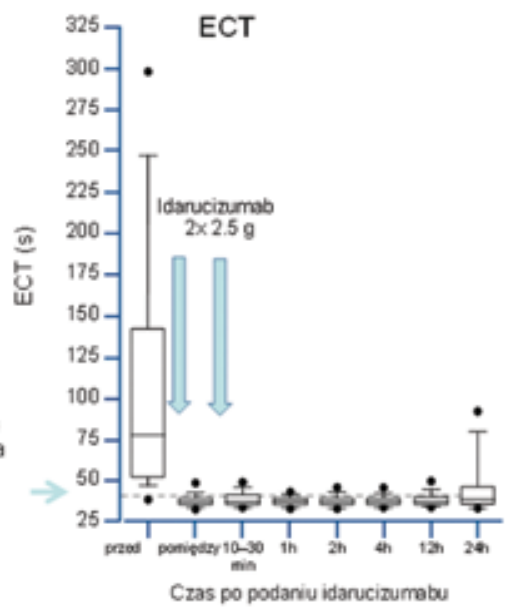

Normalizacja u $93 \%, 42 / 47 / 51$

Rycina 5. Pierwszorzędowy punkt końcowy: odwrócenie działania przeciwzakrzepowego dabigatranu przez idarucizumab na podstawie czasu trombinowego w rozcieńczonym osoczu (dTT, diluted thrombin time) i ekarynowego czasu krzepnięcia (ECT, ecarin clotting time) w grupie chorych z krwawieniem - czynne krwawienie ocenione przez lekarza jako wymagające pilnego podania antidotum (zmodyfikowano wg [9]) 
Poważne działania niepożądane w czasie trwania badania wystąpiły u 21 chorych (13 w grupie A i 8 w grupie B). Oprócz 18 zgonów i epizodów zakrzepowych, które wystąpiły u 5 pacjentów, działania niepożądane obejmowały krwawienie z przewodu pokarmowego (u 2 pacjentów), zakażenie rany pooperacyjnej, zespół odstawienny, niewydolność prawej komory serca oraz obrzęk płuc (u 1 chorego). U niektórych pacjentów wystąpił więcej niż jeden skutek uboczny terapii idarucizumabem [9].

\section{Pierwszorzędowe punkty końcowe}

U 88-98\% pacjentów, którzy mieli wydłużone czasy krzepnięcia na początku badania, idarucizumab szybko i całko- wicie odwracał działanie przeciwkrzepliwe dabigatranu. Wyrażało się to normalizacją dTT i ECT zarówno w grupie chorych z niekontrolowanym krwawieniem (ryc. 5), jak i w grupie chorych wymagających nagłego zabiegu lub procedury inwazyjnej (ryc. 6). Idarucizumab zniwelował potrzebe interwencji u 1 z 3 pacjentów w grupie B, który nie został poddany zabiegowi. Spośród 36 chorych, którzy przebyli zabieg, u 92\% odnotowano prawidłową hemostaze, a u pozostałych $8 \%$ łagodnie lub umiarkowanie upośledzoną. Mimo że średni czas do ustania krwawienia w grupie A wyniósł 11,4 godziny, zmienna ta była trudna do oceny $u$ wielu pacjentów, na przykład u chorych z krwawieniem wewnątrzczaszkowym lub zaotrzewnowym. Tylko u 1 z 90

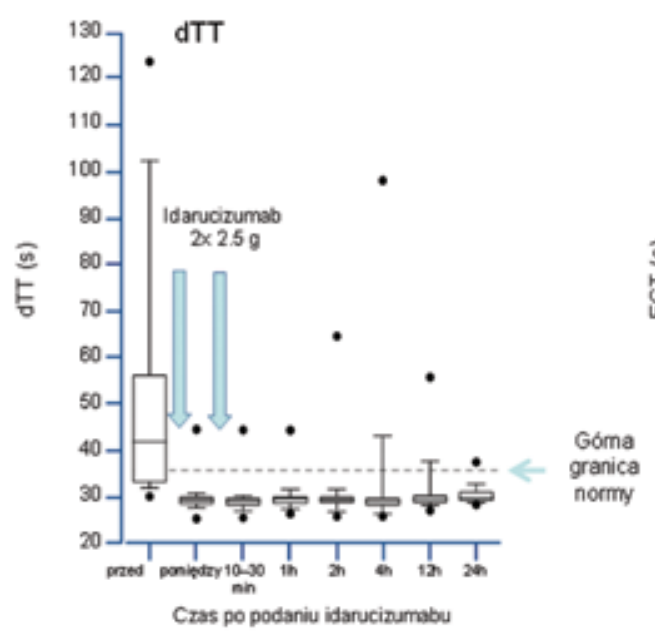

Normalizacja u $93 \%, 27 / 28 / 39$

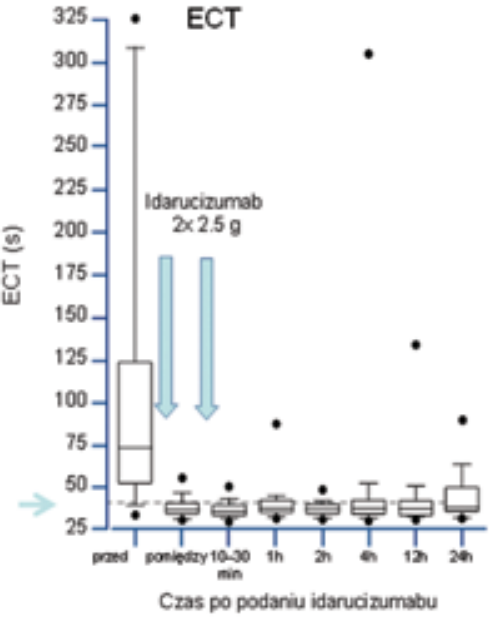

Normalizacja u $88 \%, 30 / 34 / 39$

Rycina 6. Pierwszorzędowy punkt końcowy: odwrócenie działania przeciwzakrzepowego dabigatranu przez idarucizumab na podstawie czasu trombinowego w rozcieńczonym osoczu (dTT, diluted thrombin time) i ekarynowego czasu krzepnięcia (ECT, ecarin clotting time) w grupie pacjentów chirurgicznych - chorzy wymagający pilnej interwencji zabiegowej z przyczyn innych niż krwawienie (zmodyfikowano wg [9])
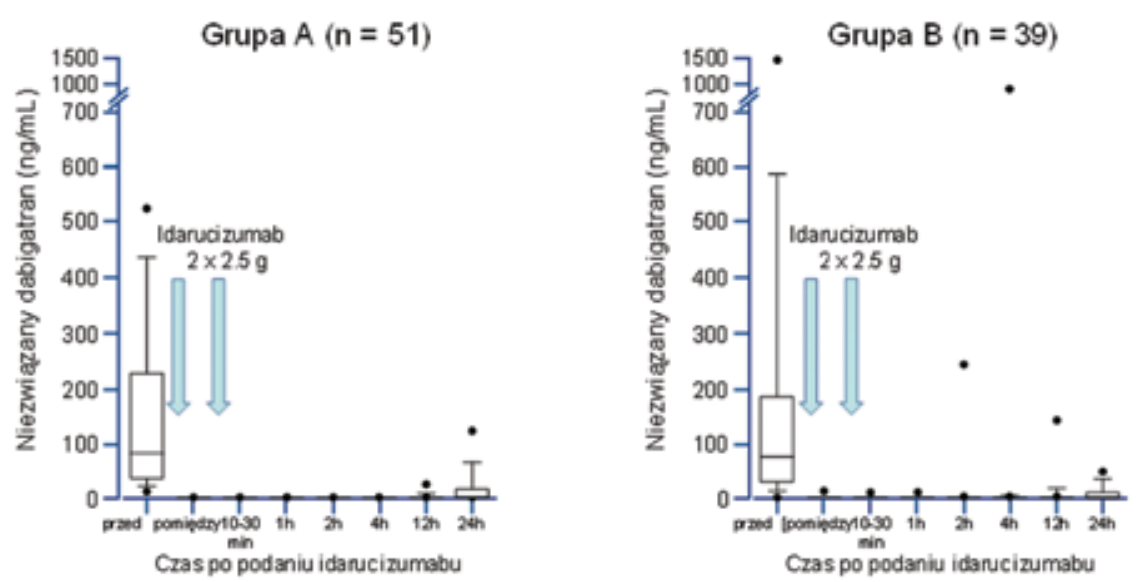

Rycina 7. Stężenia dabigatranu przed i po podaniu idarucizumabu (zmodyfikowano wg [9]) - wartości dabigatranu obniżyły się poniżej $20 \mathrm{ng} / \mathrm{ml} \mathrm{u} 89 / 90$ pacjentów już po podaniu pierwszej fiolki, wartości niezwiązanego dabigatranu wynosiły poniżej $20 \mathrm{ng} / \mathrm{ml}$ u 77/83 pacjentów i 62/78 (79\%) pacjentów po, odpowiednio, 12 i 24 h. Stężenie niezwiązanego dabigatranu poniżej 20 ng/ml odpowiada stężeniu dającemu mały efekt przeciwzakrzepowy lub żadnego 
pacjentów (1\%) wystąpił epizod zakrzepowy w przeciągu 72 godzin od podania idarucizumabu - u tego chorego nie włączono powtórnie leczenia przeciwkrzepliwego [9].

Stężenie niezwiązanego dabigatranu zostało zredukowane do poziomu lub dolnej granicy oznaczenia ilościowego u wszystkich poza 1 chorym (ryc. 7) [9].

\section{Podsumowanie}

Wprowadzenie OAC stało się przed laty kamieniem milowym w profilaktyce pierwotnej i wtórnej powikłań zakrzepowo-zatorowych. Klasyczne OAC mają jednak wiele znanych ograniczeń, skutkujących z jednej strony zmniejszeniem skuteczności działania przeciwzakrzepowego, z drugiej zaś istotnie zwiększających ryzyko powikłań krwotocznych.

Nowe doustne antykoagulanty w istotny sposób zmniejszyły niedogodności oraz ryzyko związane z zastosowaniem leków poprzedniej generacji. Mimo iż znacznie poprawiły skuteczność leczenia przeciwzakrzepowego, ich zasto- sowanie nadal wymaga specjalnej uwagi w odniesieniu do potencjalnych powikłań krwotocznych związanych z ich stosowaniem. Dotyczy to zwłaszcza sytuacji nagłych, a mianowicie groźnych dla życia krwawień oraz sytuacji klinicznych, w których konieczne jest szybkie odwrócenie działania leku.

Jak dotąd w przypadku NOAC nie istniała możliwość skutecznego, specyficznego i szybkiego odwracania efektu antykoagulacyjnego działania leków. Wprowadzenie idarucizumabu po raz pierwszy wśród NOAC pozwala na szybkie i skuteczne zahamowanie działania dabigatranu. Niewątpliwie wpłynie to istotnie na bezpieczeństwo stosowania leku, co zapewne zwiększy zaufanie zarówno lekarzy, jak i chorych do zastosowania tej formy leczenia antykoagulacyjnego.

\section{Konflikt interesów}

Tomasz Zapolski: wykłady naukowe dla Boehringer Ingelheim.

\section{Abstract}

Chronic anticoagulation therapy applies to the treatment and prevention of thromboembolic complications. Those were vitamin $\mathrm{K}$ antagonists that used to be a standard within many years. Their usage is associated with enhanced bleeding risk, augmented risk of interactions with numerous agents as well as with the need of continuous monitoring of the blood coagulation system.

Due to limitations in VKA therapy, non-vitamin $\mathrm{K}$ antagonists (dabigatran, rivaroxaban and apixaban) were synthesized within last years. A direct thrombin inhibitor - dabigatran etexilate was the first agent of this group to have been joined to the range of recommended anticoagulant drugs.

The positive aspect of dabigatran introduction appeared to be no necessity of its anticoagulant effect monitoring in every day clinical practice taking into account dabigatran's short half-life, wide therapeutic window and usage of drug's constant doses in clinical trials.

Adverse effects of dabigatran include serious, life-threatening bleedings. Not less essential is the need of its anticoagulant effect rapid reversal in patients requiring urgent surgery or bleeding inhibition. Therefore, developing an effective antidote is needed, which could reverse anticoagulation caused by dabigatran quickly and specifically.

This review presents difficulties in etexilate dabigatran's action monitoring, clinical problems in patients undergoing therapy with dabigatran. It also discloses the results of a prospective, cohort study RE-VERSE AD (Reversal Effects of Idarucizumab on Active Dabigatran), in which effectiveness and safety of idarucizumab - specific antidote for an agent was examined in reversing anticoagulant action in patients with serious bleeding or in those necessitating urgent surgical intervention.

Key words: dabigatran, idarucizumab, anticoagulation, bleeding complications

Folia Cardiologica 2016; 11, 4: 284-292 


\section{Piśmiennictwo}

1. Holbrook A., Schulman S., Witt D.M. i wsp. Evidence-based management of anticoagulant therapy: Antithrombotic Therapy and Prevention of Thrombosis, 9th Ed: American College of Chest Physiciancs Evidence-Based Clinical Practice Guidelines. Chest 2012; 141 (supl. 2): e152S-e184S.

2. Pollack C.V. Jr. Coagulation assessment with the new generation of oral anticoagulants. Emerg. Med. J. 2016; 33: 423-430.

3. Ageno W., Gallus A.S., Wittkowsky A. i wsp. Oral anticoagulant therapy: antithrombotic therapy and prevention of thrombosis, 9th Ed: American College of Chest Physicians Evidence-Based Clinical Practice Guidelines. Chest 2012; 141: e44S-88S.

4. Pradaxa (dabigatran) packane insert. Ridgefield, CT: Boehringer Ingelheim Pharmaceuticals; 2011.

5. Beyer-Westendorf J., Ageno W. Benefit-risk profile of non-vitamin K antagonist oral anticoagulants in the management of venous thromboembolism. Thromb. Haemost. 2014; 16: 113-128.

6. Bayer Pharma AG. Xarelto (Rivaroxaban) Xarelto summary of Product Characteristics - EU 2013. Available at: http://www.xarelto.com/en/ /information-on-xarelto/summary-of-product-characteristics/.

7. Eliquis Product Monograph Canada. 2012.

8. Desai N.R., Krumme A.A., Schneeweiss S. i ws.. Patterns of Initation of Oral Anticoagulants in Patients with Atrial Fibrillation - Quality and Cost Implications. Am. J. Med. 2014; 127: 1075-1082.e1.

9. Pollack C.V., Reilly P.A., Eikelboom J. i wsp. Idarucizumab for Dabigatran Reversal. NEJM 2015; 373: 511-520.

10. Ansell J., Hirsh J., Hylek E. i wsp. Pharmacology and Management of the Vitamin K Antagonist. American College of Chest Physicians Evidence-Based Clinical Practice Guidelines (8th Edition). Chest 2008; 133: $160 \mathrm{~S}-198 \mathrm{~S}$

11. Umer Ushman M.H., Raza S., Raza S., Ezekowitz E. Advancement in antithrombotics for stroke prevention in atrial fibrillation. J. Interv. Card. Electrophysiol. 2008; 22: 129-137.

12. Weitz J., Hirsh J., Samama M.M. New antithrombotic drugs. american college of chest physicians evidence-based clinical practice guidelines (8th edition). Chest 2008; 133: 234-256.

13. van Ryn J., Baruch L., Clemens A. Interpretation of point-of-care INR results in patients treated with dabigatran. Am. J. Med. 2012; 125: 417-420.

14. Stangier J., Rathgen K., Stahle H. i wsp. The pharmacokinetics, pharmacodynamics and tolerability of dabigatran etexilate, a new oral direct trombin inhibitor, in health male subjects. Br. J. Clin. Phrmacol. 2007; 64: 292-303.

15. van Ryn J., Stangier J., Haertter S. i wsp. Dabigatran etexilate - a novel, reversible, oral direct trombin inhibitor; interpretation of coagulation assays and reversal of anticoagulant activity. Thromb. Haemost. 2010; 103: 1116-1127.

16. Lindahl T.L., Baghaei F., Blixter I.F. i wsp. Effects of the oral, direct trombin inhibitor dabigatran on five common coagulation assays. Throm. Haemost. 2011; 105: 371-378.

17. Stangier J., Clemens A. Pharmacology, pharmacokinetics, and pharmacodynamics of dabigatran etexilate, an oral direct thrombin inhibitor. Clin. Appl. Thromb. Hemost. 2009; 15 (supl. 1): 9S-16S.

18. Pruszczyk P., Stępińska J., Banasiak W. i wsp. Zastosowanie nowych doustnych leków przeciwkrzepliwych w prewencji powikłań zatorowych u chorych z migotaniem przedsionków. Stanowisko grupy ekspertów Polskiego Towarzystwa Kardiologicznego, Polskiego Towarzystwa Neurologicznego i Grupy ds. Hemostazy Polskiego To- warzystwa Hematologów i Transfuzjologów. Kardiol. Pol. 2012; 70: 979-988.

19. Husiman M.V., Lip G.Y., Diener H.C. i wsp. Dabigatran eteksilate for stroke prevention in patients with atrial fibrillation: resolving uncertainties in routine practice. Thromb. Haemost. 2012; 107: 838-847.

20. Lauffenburger J.C., Rhoney D.H., Farley J.F. i wsp. Predictors of gastrointestinal bleeding among patients with atrial fibrillation after initiating dabigatran therapy. Pharmacotherapy 2015; 35: 560-568.

21. van Ryn J., Sieger P., Kink-Eiband M. i wsp. Adsorption of dabigatran etexilate in water or dabigatran in pooled human plasma by activated charcoal in vitro. Paper presented at 51st American Society of Hematology Annual Meeting and Exposition. New Orleans; 2009 (abstrakt).

22. Suryanarayan D., Schulman S. Potential antidotes for reversal of old and new oral anticoagulants. Thromb. Res. 2014; 133: S158-S166.

23. Heidbuchel H., Verhamme P., Allings M. i wsp. European Heart Rhythm Association Practical Guide on the use of new oral anticoagulants in patients with non-valvular atrial fibrillation. Europace 2013; 15: 625-651.

24. Bershad E.M., Suarez J.I. Prothrombin complex concentrates for oral anticoagulant therapy-related intracranial hemorrhage: a review of the literature. Neurocrit. Care 2010; 12: 404-413.

25. Octaplex product information. Octapharma, Lachen 2007.

26. Eerenberg E.S., Kamphuisen P.W., Sijpkens M.K. i wsp. Reversal of Rivaroxaban and Dabigatran by Prothrombin Complex Concentrate. Circulation 2011; 124: 1573-1579.

27. Marlu R., Hodaj E., Paris A. i wsp. Effect of nonspecific reversal agents on anticoagualnt activity of dabigatran and rivaroxaban. A randomised crossover ex vivo study in health volunteers. Thromb. Hameost. 2012; 108: $217-224$.

28. Monroe D.M., Hoffman M., Oliver J.A. i wsp. Platelet activity of high-dose factor VII is independent of tissue factor. Br. J. Haematol. 1997; 99: 542-547.

29. van Ryn J., RuehI D., Priepke H. i wsp. Reversibility of the anticoagulant effect of high doses of the direct thrombin inhibitor dabigatran, by recombinant factor VIla or activated prothrombin complex concentrate. Haematologica 2008: 148 (abstrakt).

30. Lippi G., Favaloro E.J. Activated partial thromboplastin time: new tricks for an old dogma. Semin. Thromb. Hemost. 2008; 34: 604-611.

31. Warkentin T.E., Margetts P., Connolly S.J. i wsp. Recombinant factor VIla (rFVIla) and hemodialysis to manager Massie dabigatran-associated postcardiac burgery bledding. Blood 2012; 119: 2172-2174.

32. Tran H., Joseph J., Young L. i wsp. New oral anticoagulants: a practical guide on prescription, laboratory testing and peri-procedural/bleeding management. Internal Med. J. 2014; 44: 525-536.

33. Schiele F., van Ryn J., Canada K. i wsp. A specific antidote for dabigatran: functional and structural characterization. Blood 2013; 121 : 3554-3562.

34. Glund S., Moschetti V., Norris S. i wsp. A randomised study in healthy volunteers to investigate the safety, tolerability and pharmacokinetics of idarucizumab, a specific antidote to dabigatran. Thromb. Haemost. 2015; 113: 943-951.

35. Glund S., Stangier J., Schmohl M. i wsp. Idarucizumab, a specific antidote for dabigatran: immediate, complete and sustained reversa of dabigatran induced anticoagulation in elderly and renally impaired subjects. Blood 2014; 124: 344 (abstrakt).

36. Glund S., Stangier J., Schmohl M. i wsp. Safety, tolerability, and efficiacy of idarucizumab for the reversal of the anticoagulant effect of dabigatran in healthy male volunterrs: a randomised, placebo-controlled, double-blind phase 1 trial. Lancet 2015; 386: 680-690. 